\title{
On the Constitutive Equation for Polymeric Materials
}

\author{
by \\ Hirokazu Kajiura, Mototsugu Sakai* and Mitsuru Nagasawa \\ Department of Synthetic Chemistry, Faculty of Engineering, Nagoya University, Chikusa-ku, Nagoya
}

The validities of the linear and nonlinear constitutive equations for polymeric materials are discussed from non-steady experiments with a Weissenberg rheogoniometer model R-17 of Sangamo Controls. Lodge's linear constitutive equation is well supported by the measurements of normal and shear stresses under oscillatory shear flow. On the other hand, the socalled "rate type" nonlinear constitutive equation could not explain the experimental results of the stress growth and relaxation after the onset and the cessation of steady simple shear flow. A discussion on the failure of the theories for stress-overshoot phenomena is given based on the idea that a transition of the internal structure due to external force does not occur at the moment when the external force is given to the material but occurs after a certain amount of strain is accumulated in the material. Moreover, a method to estimate the energy for entanglement destruction in polymeric materials is proposed.

* Present address : Showa Denko Manufacturing Co., Ltd., Oomachi-shi, Naganoken

\section{高分子溶液に対する構成方程式について}

\author{
梶浦＼cjkstart博一・逆井 基次・永沢＼cjkstart満*
}

（原稿受理：1974年10月 3 日）

\section{1. 序}

高分子溶液の粘弾性挙動を記述するレオロジー構成方程式は, 比較的に取り扱いが簡単な積分型の方程式群を中心に発展してき た。それらの理論の多くは線形領域では次の簡潔な形式で表現さ れる1).

$$
\left.\boldsymbol{P}+p \mathbf{1}=\int_{-\infty}^{t} \mu^{\prime} t, t^{\prime}\right) \lambda\left(t, t^{\prime}\right) d t^{\prime}
$$

こてで $\boldsymbol{P}$ は全応力テンソル， $p$ は等方压力， $\mu$ は記憶関数, $\lambda\left(t, t^{\prime}\right)$ は第一（あるいは Finger）歪テンソルである，ての方程 式に含まれる記憶関数 $\mu$ は時間差 $\left(t^{\prime}-t\right)$ だけに依存する物質関 数である. 式(1)は歪あるいは歪速度が小さい場合には, 現象をよ く記述できる.乙れに対し, 歪あるいは歪速度が大きくなると, 当然応力テンソルと歪テンソル間に線形の関係が成立しなくなる. 歪テンソルの高次項への依存性が論じられることもあるが，一般 には取扱いの容易さのために, 式(1)における記憶関数を歪または

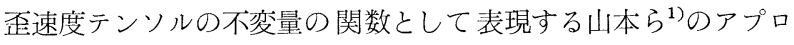

\footnotetext{
* 名古屋大学工学部合成化学教室 名古屋市千種区不老町
}

一チが広く検討されてきた。すなわち

$$
\boldsymbol{P}+p \mathbf{1}=\int_{-\infty}^{t} \mu\left(t-t^{\prime} \mid A\left(t, t^{\prime}\right)\right) \lambda\left(t, t^{\prime}\right) d t^{\prime}
$$

ここで $A\left(t, t^{\prime}\right)$ が歪テンソルの不変量である場合 (以後 $\mathrm{S}$ 型と 呼ぶ）と歪速度テンソルの不変量の場合（以後 $\mathrm{R}$ 型と呼ぶ）の二 つの場合がある．定常ずり応力，あるいは法線応力のずり速度依 存性を論ずる場合には， R 型の記憶関数2) 6) を用いるのが便利で あるのに対し，大変形下での緩和現象など $\boldsymbol{P}$ の歪依存性を論ずる 場合には ${ }^{778)} ， \mathrm{~S}$ 型の $\mu$ を用いるのが直観的に合理的かも知れな い.しかし，いずれにせよ $\mu$ を歪あるいは歪速度のみの関数と して表現するととによって，すべての非線形現象を記述できるか ぞうかを検討するととが現在の非線形レオロジ一の課題と考える。 我々は記憶関数 $\mu$ を歪速度の関数と考えた場合について検討を行 ってきたのでここでまとめて報告する.

\section{2. 理論と実験の比較方法について}

\section{$2 \cdot 1$ 線形領域}

線形領域の式(1)の実験的検討には振動変形の実験が便利であろ 
う。いま式(3)で表現される振動歪 $S$ を粘弾性体に加えると, 応答 として発生する法線応力及びずり応力は, それぞれ式(4)，(5)のよ うになる ${ }^{9) 10)}$.

$$
\begin{gathered}
S=\alpha \sin \omega t \\
P_{11}-P_{22}=\alpha^{2}\left(A_{n}+B \cos 2 \omega t+C \sin 2 \omega t\right) \\
P_{21}=\alpha\left(A_{s} \sin \omega t+D \cos \omega t\right)
\end{gathered}
$$

ここで $\alpha$ は加えたずり歪の振幅であり，十分小さいものとする. 係数 $A, B, C, D$ の間には次のような関係がある ${ }^{10)}$.

$$
\begin{aligned}
& A_{s}(\omega)=A_{n}(\omega) \\
& B(\omega)=-A(\omega)+\frac{1}{2} A(2 \omega) \\
& C(\omega)=D(\omega)-\frac{1}{2} D(2 \omega)
\end{aligned}
$$

すなわち線形構成方程式の検討には，乙れらの関係式を実験と比 較するとよい. 別に Coleman-Markovitz ${ }^{11)}$ にって指摘された 次の関係も式(1)の検討のために用いられる.

$$
\begin{aligned}
& \lim _{\dot{\gamma} \rightarrow 0} \eta(\dot{\gamma})=\lim _{\omega \rightarrow 0} \eta^{\prime}(\omega) \\
& \lim _{\dot{\gamma} \rightarrow 0}\left(\left(p_{11}-p_{22}\right) / \dot{\gamma}^{2}\right)=\lim _{\omega \rightarrow 0}\left(2 A / \omega^{2}\right)
\end{aligned}
$$

こてで $\eta^{\prime}$ は動的粘性率， $\omega$ は振動数である.

\section{$2 \cdot 2$ 非線形領域}

式(2)によっていわゆる stress overshoot 及び stress relaxation のような非定常の実験を定量的に説明できるか否かもまた近年活 発に研究されてきた。この場合には， $\mu$ はずり速度の関数である が，具体的な関数形を仮定しない方が望ましいととは言うまでも ない.

定常ずり流動停止後の応力緩和の場合には，法線応力とずり応 力の間に式(12)の関係が成立しなければならないととが山本 ${ }^{2) 3} に$ よって指摘された.

$$
-\frac{d\left(P_{11}-P_{22}\right)}{d t}=2 \dot{\gamma} P_{21}
$$

ここで $P_{i j}$ は応力成分, $\dot{\gamma}$ はずり速度, $t$ は時間である.

一方 stress overshoot 亿対しては，もしR型の $\mu$ をもつ式(2)が 妥当であるなら，式(13)が成立しなければならないととがVan Es

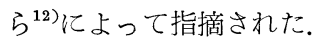

$$
\begin{aligned}
-t \eta^{d}(t) & +\int_{0}^{t} \eta^{d}(\lambda) d \lambda+{\phi_{12}}^{d}(t) \\
& =\int_{0}^{t} \lambda\left[\int_{0}^{\infty} \mu_{0}(\lambda+\xi) d \xi\right] d \lambda \equiv G(t)
\end{aligned}
$$

こてで $\eta^{d}(t)=P_{21}(t) / \dot{\gamma}, \phi_{12}{ }^{d}(t)=\left(P_{11}-P_{22}\right) / \dot{\gamma}^{2}$ である. たま $\mu_{0}$ は線形の記憶関数でずり速度に依存しない. したがって $G(t)$ を 時間 $t$ に対してプロットすれば，ずり速度に無関係な 1 本の曲線 にならなければならない。

\section{3. 実 験 結 果}

以上の理論的関係の実験的検討はワイゼンベルグレオゴニオメ ータによって行なうことができる. 本研究はすべてサンガモ社製 R-17型によって行なわれた。 市販のワイゼンベルグレオゴニオ メー夕は一般に法線応力測定の感度を増加させるために弱い法線 応力測定用スプリングを使用している. そのため非定常の実験デ ータの解析に際しては測定系の力学的インピーダンスを考慮しな ければならない13)。乙の装置の詳細, 信頼性あるいは補正方法に ついては前報 ${ }^{10) 13}$ 亿詳しく述べられている。

\section{$3 \cdot 1$ 線形領域}

市販ポリスチレン $\left(M_{v}=2.0 \times 10^{5}\right)$ の塩化ジフェニル溶液を使 用し， $4^{\circ}, 7.5 \mathrm{~cm} \phi$ の cone で $25.0 \pm 0.1^{\circ} \mathrm{C}$ 飞おいて式(1)刀検討を 行なった. 詳細は前報 ${ }^{10) 13}$ に述べられているが，その概要を総括 しておく．理論の示すように，ずり応力の振幅 $Z$ は加えたずり 歪の振幅 $\alpha$ の 1 乗に, 法線応力の変位成分 $X$ は $\alpha^{2}$ に, そして 法線応力の振動成分の振幅 $Y$ は $\alpha^{2}$ にそれぞれ比例するととが認 められた。一例を図 1 亿示す ${ }^{10)}$.

図 2 に $A_{s}$ 及び $A_{n}$ と $\omega$ のプロットを示した。 四上り明らかな ように，式(6)が成立しているてとがわかる，さらに， $d Y / d \alpha^{2}(\equiv$

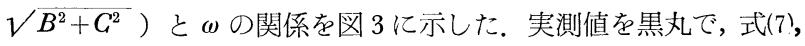
(8)からの計算値を $\times$ 印で示した。実験誤差内で理論值と実験值 が一致していると結論するてとができる ${ }^{13)}$. その他， $B$ 及び $C$ 自身も，式(7)，(8)の関係をそれぞれ満足している，また式(9)の Coleman-Morkovitz ${ }^{11)}$ の関係も実験によって支持される ${ }^{10)}$.

これらの実験結果より, 線形領域では高分子物質の粘弾性挙動 は式(1)によって記述される，また逆にワイゼンベルグレオゴニオ

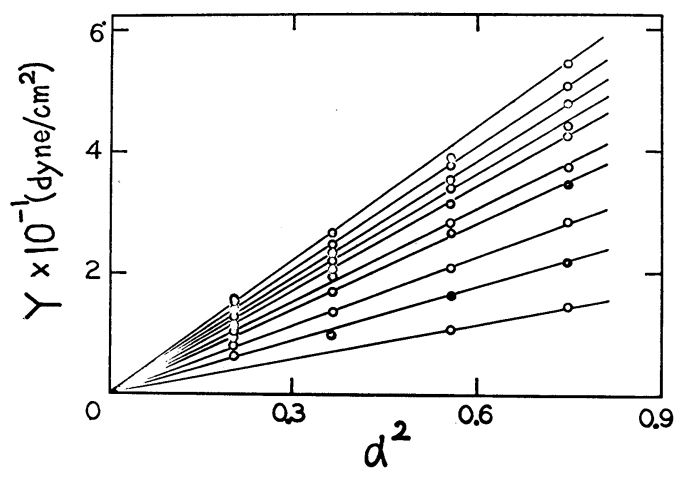

Fig. 1. Plots of normal force amplitude $Y v s . \alpha^{2}$ for a polystyrene solution $(16 \%)$ at various angular frequencies (from top to bottom) ; 37.7, 23.8, 15.0, 9.47, 5.97, 3.77, 2.38, 1.19, and 0.597. (Reproduced from ref. 10)

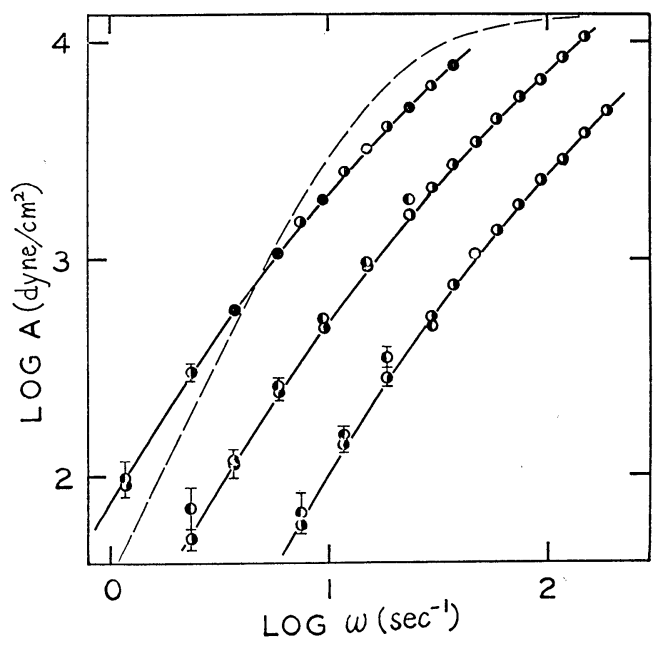

Fig. 2. Polts of $\log A_{n}, \log A_{s} v s . \log \omega$ for three polystyrene solutions of concentrations (from left to right) $16 \%, 13 \%$, and $10 \%:\left(\right.$ ) $A_{n} ;(1) A_{s}$; both $A_{n}$ and $A_{s}$. See ref. 10 for broken line. (Reproduced from ref. 10) 


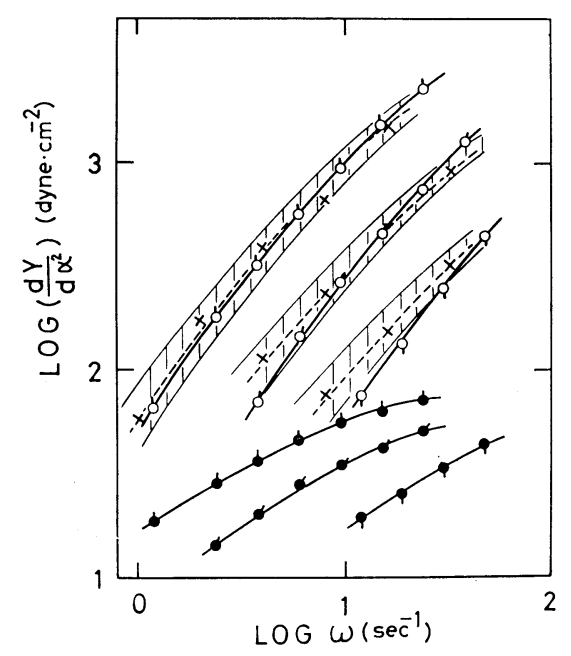

Fig. 3. Plots of $\log \sqrt{B^{2}+G^{2}}$ vs. $\log \omega$ for three samples ; $(b, b) 16 \%,(\sigma, \bullet) 13 \%,(\varphi, \varphi) 10 \% ;(\bigcirc)$ observed values; $(\times)$ values calculated from eqs $(7)$ and $(8)$. The shaded regions show the ambiguity of the calculated values. The filled circles show the data obtained without taking into account the contribution of mechanical impedance (see ref. 13). (Reproduced from ref. 13)

\section{メータによる法線応力測定が信頼し得ることが証明された。}

\section{$3 \cdot 2$ 非線形領域}

単分散ポリ- $\alpha$-メチルスチレン $\left(M_{w}=1.25 \times 10^{6}\right)$ の塩化ジフェ ニル $10 \%$ 溶液を用い， $4^{\circ}, 5 \mathrm{~cm} \phi$ cone t使用して， $25.0 \pm 0.1^{\circ} \mathrm{C}$ において，ずり流動下における stress overshoot ならびに stress relaxation を測定した．乙の実験は測定系の力学的インピーダン スによる䛊差を最小にするために，また cone-plate 間のギャッ プを一定に保つために gap-servo system を使用した6)4).

定常流動停止後の応力緩和の測定結果を図 4 亿示す. 式(12)の左 辺 $d\left(P_{11}-P_{22}\right) / d t$ を黒丸で, 右辺の $2 \dot{\gamma} P_{21}$ を白丸で示してある. ずり速度にかかわらず式(12)が成立しているととを示している ${ }^{6)}$.

stress overshoot 亿関する式(13)の $G(t)$ と時間 $t$ の関係を図 5 亿 示す ${ }^{14)}$. 実線はポリ $\alpha$-メチルスチレンの実測值を, 点線はV Van Es ら ${ }^{12)}$ にるポリイソブテンの実測值を示す，図より明らかな
ように，長時間側では 1 本の曲線を形成せず，まったく理論と一 致しない. 少くとも， stress overshoot に対しては R 型の記憶関 数を含む式(2)はそのままでは適用できないと考えられる。

\section{4. 考}

察

一般に式(1)中の記憶関数 $\mu(t)$ あるいは余効関数 $\varphi(t)$ は，緩 和スペクトル $H(\tau)$ と関係づけられる1).すなわち $\mu$ または $\varphi$ は その物質の内部状態，あるいはからみ状態を表現する物質関数と 考えてよい. 非線形領域の構成方程式(2)において $\mathrm{R}$ 型の記憶関数 を用いるととはずり速度によって物質の内部構造が変化し, 従っ て記憶関数が変化すると理解してよいであろう。このことはR 型 の典型である TYT 理論 ${ }^{2)}$ が Graessley 理論 ${ }^{15)}$ 亿基礎をおいて いることから明らかである。

stress overshoot に対するVan Es の理論式(13)はR 型の構成方 程式(2)からずり応力生長に対して, 式(14)を経て導かれた。

$$
P_{21}^{d}(t)=\dot{\gamma}\left[t \int_{0}^{\infty} \mu\left(t+t^{\prime} \mid 0\right) d t^{\prime}+\int_{0}^{t} t^{\prime} \mu\left(t^{\prime} \mid \dot{\gamma}\right)\right] d t^{\prime} \quad \text { (14) }
$$

こてで, $t=0$ から系が流動を開始すると仮定されている。すなお ちこの方程式は，流動が開始した瞬間から物質の内部構造が最後 のずり速度の状態に変化するととを仮定している.つまり $t=0$ に おいて $\mu\left(t, t^{\prime} \mid \dot{\gamma}\right)$ が用いられている。 そのために $\eta^{d}(t)$ または $\phi_{12}{ }^{d}(t)$ の $t=0$ の近傍の立ち上がりは $\dot{r}$ 亿依存するととを仮定し ている2.しかしながら，てのモデルは物理的にあまりに極端に すぎる. 少くとも $t=0$ の近傍においては物質は流動下でも $\dot{r}=0$ の構造をもっているはずであって, 物質構造の変化はある時間後 に起てるはずである。すなわち $\eta^{d}(t)$ および $\phi_{12}{ }^{d}(t)$ の立ち上が りはヴ関係せず，線形の立ち上がりを示すべきであろう。ての 推察の正しさは図 6 , 図 7 亿示された実験結果によって保証され る. 従って stress overshoot は, 図 8 亿示されるように, ある時 間経過後に物質構造が線形構造（ $\dot{\gamma}=0$ において平衡にある構造） から非線形構造に転移するてとによって生じるものである。ての ことは既に山本 ${ }^{1}$ によって指摘されている。

てのような転移現象を伴なう非定常現象を記述するために，我 々は二つの仮定を提出する。(1)上述のように記憶関数はその時か けられた歪速度あるいは見掛けの歪量に対応するものではなく， その時の物質構造（からみ点密度など）によって決定される。内

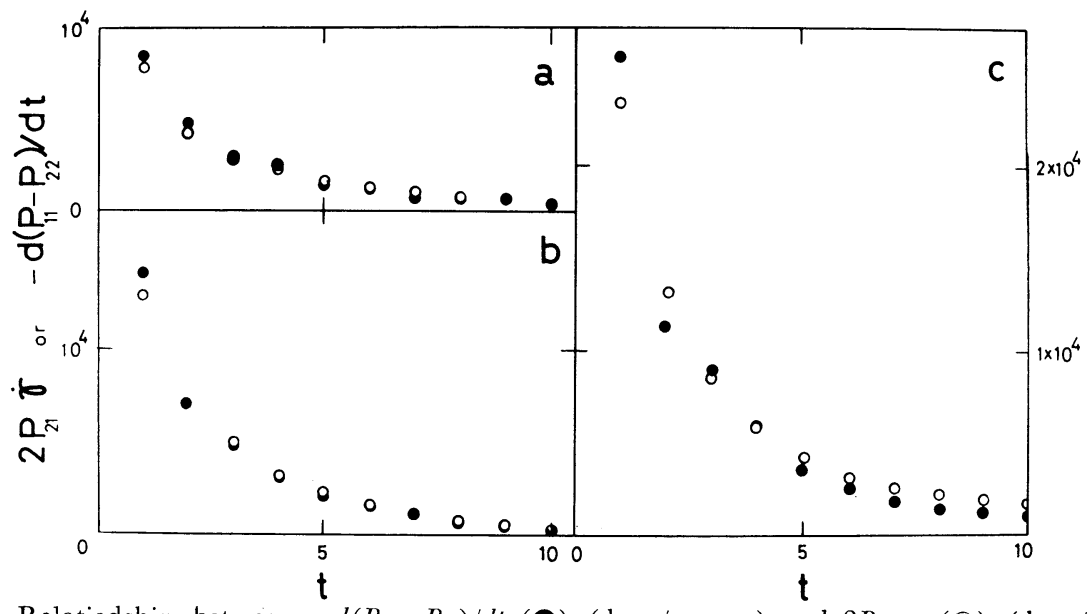

Fig. 4. Relatiodship between $-d\left(P_{11}-P_{22}\right) / d t(\bigcirc)($ dyne $/ \mathrm{cm} \cdot \mathrm{sec})$ and $2 P_{21} \dot{\gamma}(\bigcirc)$ (dyne/cm.sec) at various shear rates for a chlorinated diphenyl solution of poly- $\alpha$-styrene $(10.1 \mathrm{wt} \%)$. Shear rates $=$ (a) $0.858 \mathrm{sec}^{-1}$, (b) $1.71 \mathrm{sec}^{-1}$, (c) $4.29 \mathrm{sec}^{-1}$. (Reproduced from ref. 6) 


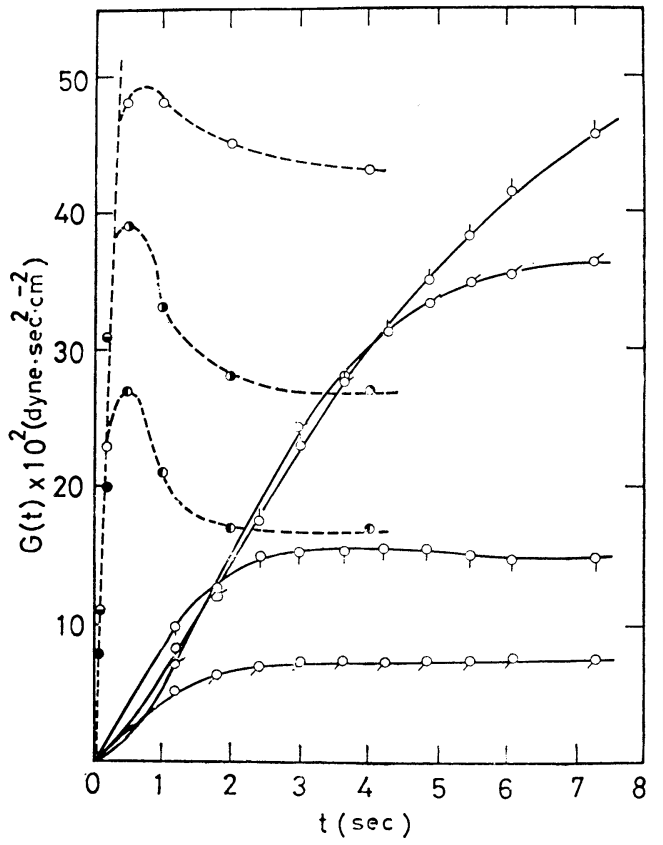

Fig. 5. Experimental test of eq (13). Sample : the same as in Fig. 4. The solid curves denote $G(t)$ at various shear rates; up pip, $0.543 \mathrm{sec}^{-1}$; up-right pip, 0.922 ; down pip, 1.71 ; down-left pip 2.72 . The dashed curves denote the data reported by Van Es and Christensen at various shear rates: (๑), $146 \mathrm{sec}^{-1} ;(\bigcirc), 92 ;(\bigcirc), 58 ;(\bullet), 37$. The data at $23 \mathrm{sec}^{-1}$ and some points at $37 \mathrm{sec}^{-1}$ are out of scale. (Reproduced from ref. 14)

部構造の転移は必ずしも力学的現象とは限らないから, てれを転 移関数 $\beta$ で表現する. (2)内部構造が変化しないような物質の粘弾 性挙動は，それが非線形状態であっても式(1)あるいは(2)の方程式 によって表現できると仮定する。てのことは少くとも線形に対し ては, 式(1)が実験 ${ }^{10113)}$ と一致するてとから妥当な仮定と考えてよ いだろう。

これらの仮定を採用すれば， stress overshoot や stress relaxation などのステップ型の非定常現象は次の方程式によって表現さ れるととになる，ただし，乙てでは記憶関数 $\mu\left(t, t^{\prime} \mid A\right)$ の代わり に余効関数 $\varphi\left(t, t^{\prime} \mid A\right)$ を採用している， $\mu$ と $\varphi$ の間には一定の 関係がある1).

$$
\begin{array}{r}
\boldsymbol{P}(t)+p \mathbf{1}=-\beta\left(t, t^{\prime \prime}\right) \int_{-\infty}^{t} \varphi\left(t, t^{\prime} \mid A\right)\left(\frac{d}{d t^{\prime}} \lambda\left(t, t^{\prime}\right)\right) d t^{\prime} \\
-\left(1-\beta\left(t, t^{\prime \prime}\right)\right) \int_{-\infty}^{t} \varphi\left(t, t^{\prime} \mid B\right)\left(\frac{d}{d t^{\prime}} \lambda\left(t, t^{\prime}\right)\right) d t^{\prime}
\end{array}
$$

とてで $A, B$ はその内部構造を示すテンソルの不変量, $\beta\left(t, t^{\prime \prime}\right)$ は転移関数であって，ずり流動の場合には，ある臨界歪 $\gamma_{c}$ まで は 1 であって，それをてえると急激に0亿減少する。すなわち物 質は歪が $\gamma_{c}$ に達した時に転移が起しると仮定する。 $t^{\prime \prime}$ は流動が 開始または停止した時間である。

ずり流動の stress overshoot と stress relaxation の際のずり応 力, 法線応力は式(15)から次のように与えられる。ただし，ての場 合には $A$ および $B$ はずり速度 0 および

$$
P_{21}{ }^{a}(t)=\dot{\gamma} \int_{0}^{t}\left[\beta^{a}(t) \varphi\left(t-t^{\prime} \mid 0\right)+\left(1-\beta^{a}(t)\right) \varphi\left(t-t^{\prime} \mid \dot{\gamma}\right)\right] d t^{\prime} \quad \text { (16) }
$$

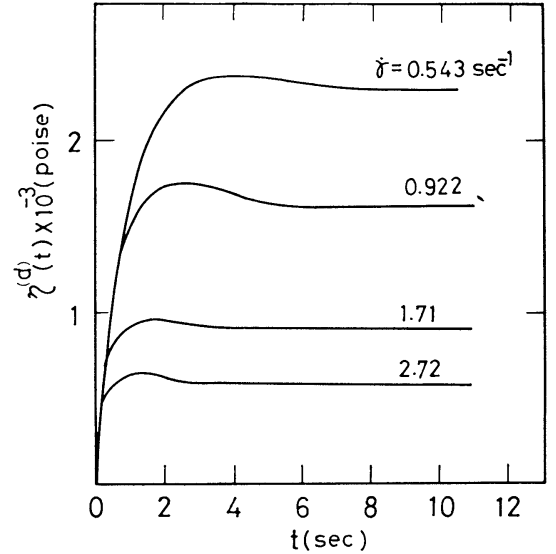

Fig. 6. The growth of shear stress $\left(\eta^{d}(t)=P_{12}^{d}(t) / \dot{\gamma}\right)$ at various shear rates. Sample; the same as in Fig. 4.

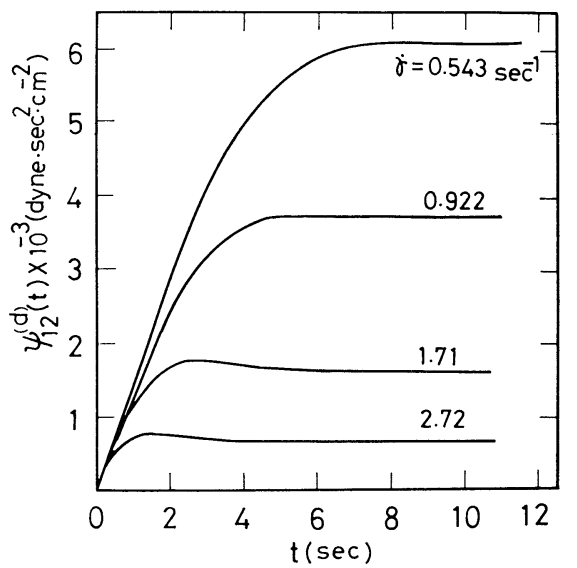

Fig. 7. The growth of normal stress $\left(\psi_{12}^{d}(t)=\left(P_{11}-P_{22}\right)^{d}\right.$ $\left./ \dot{\gamma}^{2}\right)$ at various shear rates. Sample; the same as in Fig. 4.

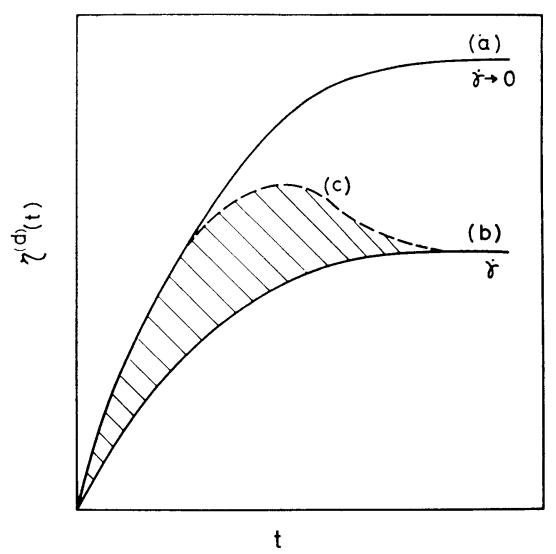

Fig. 8. A schematic graph of the stress growth under simple shear flow. The curve (a) is the stress growth in the material having the equilibrium structure. The curve (b) is that in the imaginary material having the same internal structure as at shear rate $\dot{\gamma}$. The curve (c) is that in the real material. The shaded area multiplied by $\dot{\gamma}^{2}$ is equal to the work done to transition from the equilibrium structure to the structure at $\dot{\gamma}$. 


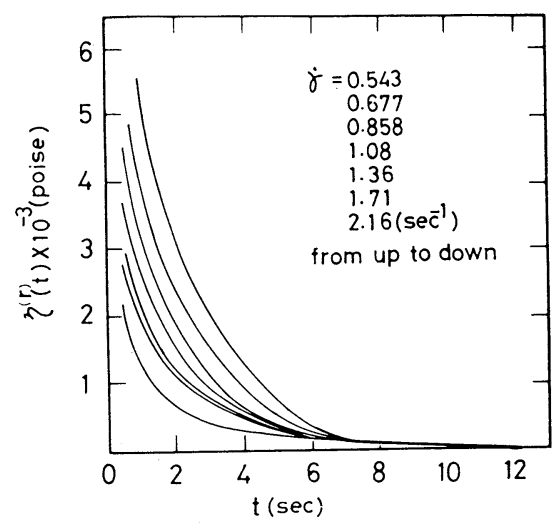

Fig. 9. The relaxation curves of $\eta^{r}(t)$ at various shear rates. The sample is the same as in Fig. 4.

$$
\begin{aligned}
\left(P_{11}-P_{22}\right)^{d}(t) & =2 \dot{\gamma}^{2} \int_{0}^{t}\left[\beta^{d}(t) \varphi\left(t-t^{\prime} \mid 0\right)\right. \\
& \left.+\left(1-\beta^{d}(t)\right) \varphi\left(t-t^{\prime} \mid \dot{\gamma}\right)\right] t^{\prime} d t^{\prime} \\
P_{21}{ }^{r}(t)=\dot{\gamma} \int_{-\infty}^{0}\left[\beta^{r}(t) \varphi\left(t-t^{\prime} \mid \dot{\gamma}\right)+\left(1-\beta^{r}(t)\right) \varphi\left(t-t^{\prime} \mid 0\right) d t^{\prime}\right. & \\
\left(P_{11}-P_{22}\right)^{r}(t) & =2 \dot{\gamma}^{2} \int_{-\infty}^{0}\left[\beta^{r}(t) \varphi\left(t-t^{\prime} \mid \dot{\gamma}\right)\right. \\
& \left.+\left(1-\beta^{r}(t)\right) \varphi\left(t-t^{\prime} \mid 0\right)\right] t^{\prime} d t^{\prime}
\end{aligned}
$$

ここでは，流動の開始または停止時間 $t^{\prime \prime}$ を零にとってある。添 字 $(d)$ 及び $(r)$ はそれぞれ stress overshoot, stress relaxation を意 味する. $\beta(t)$ の関数形が与えられなければ定量的な実測倠と計算 值の比較はできないが， $\beta$ が上述のような単調な転移関数である と仮定す机，図6，7，9に示した stress ovesshootと stress relaxationの寒験結果を定性的にはよく説明できる.

例えば stress overshootにおいて，式(13)で定義した $G(t)$ は 以下の歪では次式で与えられ，ずり速度に無関係になる。

$$
G(t)=\frac{1}{2} \phi_{12}{ }^{d}(t \mid 0) \quad t \leqq t_{c}
$$

また $t \rightarrow \infty の$ 極限では

$\lim _{t \rightarrow \infty} G(t)=\int_{0}^{\infty} \beta(t)\left[\bar{\eta}^{d}(t \mid 0)-\bar{\eta}^{d}(t \mid \dot{\gamma})\right] d t+\frac{1}{2}{\overline{\psi_{12}}}^{d}(\infty \mid \dot{\gamma})$ (21) となる. こてで, $\bar{\eta}^{d}(\mathrm{t} \mid \dot{\gamma})$, 及び $\bar{\psi}_{12}{ }^{d}(t \mid \dot{\gamma})$ は, その物質の内部構 造が常に $\dot{\gamma} の$ 状態にあると仮定した場合の見掛けの非定常粘幽: 係数及び非定常法線芯力係数であって，余効関数 $\varphi(t \mid \dot{\gamma})$ を用い て次のように定義されている。

$$
\begin{gathered}
\bar{\eta}(t \mid \dot{\gamma})=\int_{0}^{t} \varphi(\lambda \mid \dot{\gamma}) d \lambda \\
\bar{\phi}_{12}(t \mid \dot{\gamma})=2 \int_{0}^{t} \varphi(\lambda \mid \dot{\gamma}) \lambda d \lambda
\end{gathered}
$$

従った，次の関係がある.

$$
t \bar{\eta}(t \mid \dot{\gamma})-\int_{0}^{t} \bar{\gamma}(\lambda \mid \dot{\gamma}) d \lambda=\frac{1}{2} \bar{\psi}_{12}(t \mid \dot{\gamma})
$$

もしふふ(t)が次のようにステップ関数で表現できると仮定す扎゙

$$
\beta(t)= \begin{cases}1 & t \leqq t_{c} \\ 0 & t>t_{c}\end{cases}
$$

式(24)の関係式を利用して，式(21)は次のように変形される.

$$
\begin{aligned}
\lim _{t \rightarrow \infty} G(t) & =t_{c}\left[\eta^{d}\left(t_{c} \mid 0\right)-\eta^{d}\left(t_{c} \mid \dot{\gamma}\right)\right] \\
& -\frac{1}{2}{\phi_{12}}^{d}\left(t_{c} \mid 0\right)+{\psi_{12}}^{d}(\infty \mid \dot{\gamma})
\end{aligned}
$$

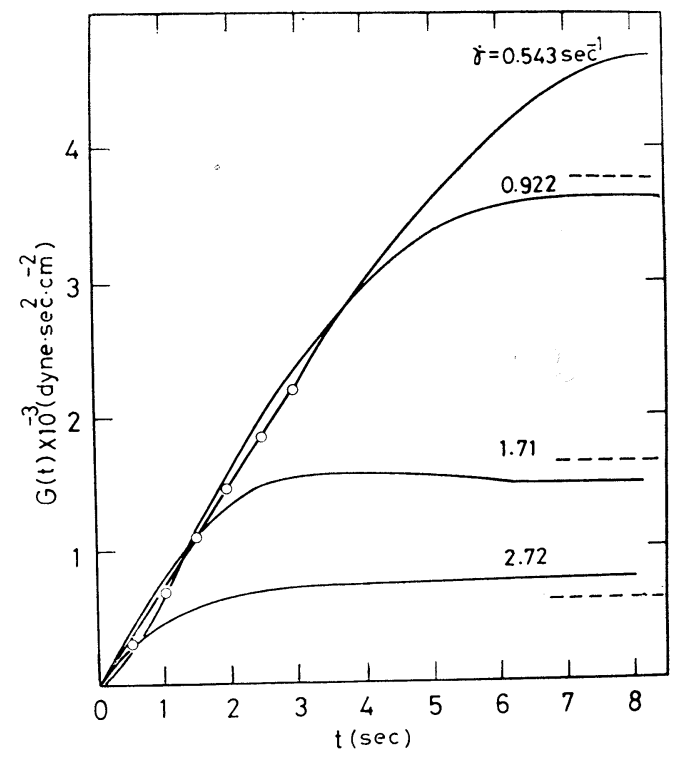

Fig. 10. The plots of $G(t)$ vs. $t$ at various shear rates. The solid curves denote the observed values shown in Fig. 5. The open circles denote $(1 / 2)$ ${\psi_{12}}^{d}(t \mid 0)$. The broken lines denote $\phi_{12}{ }^{d}(\infty \mid \dot{\gamma})$ at respective shear rates.

$t_{c}$ の評価にはある程度のあいまいさが含まれるが，いずれにせよ $t_{c}\left[r_{i}^{d}\left(t_{c} \mid 0\right)-r^{d}\left(t_{c} \mid \dot{\gamma}\right)\right]-\phi_{12}{ }^{d}\left(t_{c} \mid 0\right) / 2$ は非常に小さい値であるて 之は実測值を用いて確認できるから，

$$
\lim _{t \rightarrow \infty} G(t) \fallingdotseq \phi_{12}^{d}(\infty \mid \dot{\gamma})
$$

と結論してよいであろう。式(20)と(27)の結論は stress overshoot や stress relaxation が構造の転移によって起しることを仮定し なければ得られないであろう。

式(20)と(27)式が実験と良い一致を示すととは図10亿見られる。 $\dot{\gamma}=0$ における $\psi_{12}{ }^{d}(t)$ vs. $t$ のグラフは得られていないが, 図 7 の $\dot{\gamma}=0.543 \mathrm{sec}^{-1}$ のグラフの立ち上りは $\dot{\gamma}=0$ の極限值に近いと 仮定してよいであろう。そその仮定を用いて $\frac{1}{2} \psi_{12}{ }^{a}(t \mid 0)$ と図 5 の $G(t)$ とを比較したものが図10である。 $t \rightarrow 0$ では式(20)がよく実 験と一致するととが見られる。このととは同時に少くとも $\dot{r}=0$ の極限では式(24)の関係が満足されているとと示している。 また $t$ $\rightarrow \infty$ 極限では, $G(t)$ はほぼ $\phi_{12}{ }^{d}(\infty \mid \dot{\gamma})$ に一致するてとも図10 に見られる。ささらに $t_{c}$ をバラメータと考元, 転移点付近の適当 な值を用いるならば，式(26)の計算值と図10の $t \rightarrow \infty$ の極限とを完 全に一致させるととができる。また $t_{c}$ は必ずしも $\gamma_{c} / \dot{r}$ に等しく ないが，ほぼ $t_{c} \propto \gamma / \dot{r}$ の関係があるであ万う。図10のデー夕は この関係も定性的に满足しているように見える.

stress relaxation においては, 物質構造の変化すなわちからみ の形成が起る，ての構造形成は必ずしも力学現象ではなくて，熱 力学的現象も含まれている. 構造形成の緩和時間は必ずしも力学 的緩和の緩和侍間と対比できるかどうか明らかではない. 式(2)の $\mu$ が $\mu(t \mid 0)$ であるか $\mu(t \mid \dot{\gamma})$ であるかは別にして， $\mu$ が力学緩和 の間中一定に保たれているならば，式(12)は成立するはずである. またその場合には，すべての緩和曲線は縦軸に平行移動させるて とによって重稀わせるてとができるはずである。この条件は初 期緩利においては満足されているようにみえる(6)7)16). 
次に式(15)から構造変化に必要なエネルギーつまり“からみ点” を破壊するに必要なエネルギーが計算できることを指摘しておて う. stress overshoot の実験において，外界が $t$ 時間内に物質に 対してなした仕事 $W$ は次式で与えられる。

$$
W=\dot{r}^{2} \int_{0}^{t} \eta^{d}\left(t^{\prime}\right) d t^{\prime}
$$

一方, 初めから，その物質がずり速度字に対応する構造をもって いたと仮定するならば，その仮想的物質に外界がする仕事 $W \dot{\gamma}$ は 式(29)になるはずである。

$$
W_{\dot{\gamma}}=\dot{\gamma}^{2} \int_{0}^{t} \bar{\eta}^{d}\left(t^{\prime} \mid \dot{\gamma}\right) d t^{\prime}
$$

いま $t$ を定常状態に達したあとのある時間 $t_{s}$ にとるならば，式 (24)の関係式を用いて，次式を得る。

$$
W \dot{\gamma}=\dot{\gamma}^{2}\left(t_{s} \bar{\eta}^{d}\left(t_{s} \mid \dot{\gamma}\right)-\frac{1}{2} \bar{\psi}_{12}{ }^{d}\left(t_{s} \mid \dot{\gamma}\right)\right) \quad \text { (30) }
$$

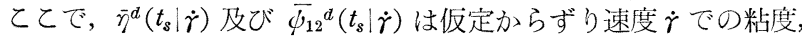
及び法線応力係数の定常值であり，乙れらの值は央測できる量で ある． $t_{s}$ においては測定試料と仮想的物質は同じ構造をとるはず であるから，以上の二つの過程でそれぞれの系に対して外界がな した仕事の差は，線形構造から夏に対応する構造へ転移させるた めになされた仕事，すなわちからみを破壊するための仕事 $E$ 々 考えることができる。

$$
E=W-W_{\dot{\gamma}}
$$

なお式(11)を誘導するときには，転移関数 $\beta(t)$ 亿何ら具体的な関 数形を仮定しなかった，図によってての計算を説明すれば，W は図 8 の曲線(c)の下の面積， $W_{\dot{\gamma}}$ は(b)の下の面積に刘応し， $E$ は 斜線の面積に対応し，それと $\dot{r}^{2} の$ 積である.

いま，からみ間分子量 $M_{e}=1.2 \times 10^{4}$ を仮定すれば ${ }^{17)}$ ，溶液中 におけ当 1 分子当りのからみ点の数は計算できる（約 11 個）。 たその数のずり速度による減少量は Graessley $\left.{ }^{15}\right) の g(\theta)$ 関数で計 算できる。図11の縦軸は実験によって決定された単位体積中のか らみをてわす仕事量，横軸は上述のように推定された高分子 1 個 あたりに減少したからみの割合を示す。罒から明らかなように， $(1-g(\theta)) \fallingdotseq 0.8$ のとてろで臨界点が存在するように見える。 $\dot{\gamma}=$ 0 における分子当りのからみ点は約11個であるから，乙の臨界点 では分子当り約 2 個の “からみ”が残っているととを意味する。

すなわち分子当り 2 個のからみは，乙れを破壊するのに大きな エネルギーを必要とし，残りは小さいエネルギーでよいようにみ

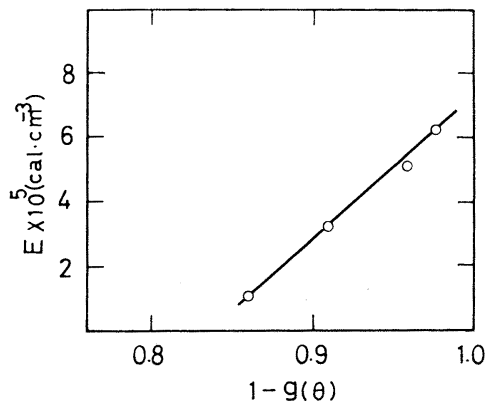

Fig. 11. The plots of $\mathrm{E}$ vs. $(1-g(\theta))$. The energy is calculated by eq (29).
える．からみ点の性質に二種類あるかも知れないととは，逆井 $ら^{18)}$ のデータからも推定できる，直線の傾きから，からみ 1 個当

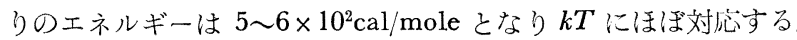

最後に式(15)の方程式は明らかに Coleman ら ${ }^{19}$ によって定義さ れた mechanical constitutive equation ではない. 式(15)に含ま れている転移関数 $\beta(t)$ は力学変数のみならず，熱力学的変数の 関数となるであろう。 Coleman ${ }^{199}$ にっって指摘されているよう なより一般的な構成方程式の確立が望まれる。

謝 辞 この研究は, 故山本三三三教授の絶えざるご指導のも とに行なわれたものであります。心から山本教授の御冥福を祈り ます。

(昭和 49 年 5 月 27 日，日本レオロジー学会第 1 年会にて発表)

\section{文献}

1）山本三三三，“物体の変形学”（1972）, 誠文堂新光社，東京。

2) Tanaka, T., M. Yamamoto, and T. Takano, J. Macromol. Sci. (Phys.), B4, 931 (1970).

3) Yamamoto, M., Trans. Soc. Rheol., 15, 331 (1971).

4) Bird, R.B., and P.J. Carreau, Chem. Eng. Sci., 23, 427 (1968).

5) Chen, I.J., and D.C. Bogue, Trans. Soc. Rheol., 16, 59 (1972).

6) Sakai M., H. Fukaya, and M. Nagasawa, Trans. Soc. Rheol., $16: 4,635$ (1972).

7) Einaga, Y., K. Osaki, M. Kurata, S. Kimura, N. Yamada, and M. Tamura, Polymer J., 5, 91 (1973).

8) Osaki, K., Y. Einaga, M. Kurata, N. Yamada, and M. Tamura, Polymer J., 5, 183 (1973).

9) Lodge, A.S., "Elastic Liquids", Chap. 7 (1964), Academic Press, New York-London.

10) Endo, H., and M. Nagasawa, J. Polym. Sci., A-2, 8, 371 (1970).

11) Coleman, B.D., and H. Markovitz, J. Appl. Phys., 35, 1 (1964).

12) Van Es, H.E., and R.M. Christensen, Trans. Soc. Rheol., 17, 325 (1973).

13) Kajiura, H., H. Endo, and M. Nagasawa, J. Polym. Sci., A-2, 11, 2371 (1973).

14) Sakai, M., H. Kajiura, and M. Nagasawa, Tran. Soc. Rheol., 18 : 2, 323 (1974).

15) Graessley, W.W., J. Chem. Phys., 43, 2696 (1965) ; 47, 1942 (1967).

16) Rokudai, M., and T. Fujiki, J. Appl. Polym. Sci., Sym. 20, 23 (1973).

17) Fujimoto, T., N. Ozaki, and M. Nagasawa, J. Polym. Sci., A-2, 6, 129 (1968)

18) Sakai, M., T. Fujimoto, and M. Nagasawa, Macromolecules, 5, 786 (1972).

19) Coleman, B. D., H. Markovitz, and W. Noll, "Viscometric Flow of Non-Newtonian Fluids" (1966), Springer, Berlin. 